Issued by Sandia National Laboratories, operated for the United States Department of Energy by Sandia Corporation.

NOTICE: This report was prepared as an account of work sponsored by an agency of the United States Government. Neither the United States Government, nor any agency thereof, nor any of their employees, nor any of their contractors, subcontractors, or their employees, make any warranty, express or implied, or assume any legal liability or responsibility for the accuracy, completeness, or usefulness of any information, apparatus, product, or process disclosed, or represent that its use would not infringe privately owned rights. Reference herein to any specific commercial product, process, or service by trade name, trademark, manufacturer, or otherwise, does not necessarily constitute or imply its endorsement, recommendation, or favoring by the United States Government, any agency thereof, or any of their contractors or subcontractors. The views and opinions expressed herein do not necessarily state or reflect those of the United States Government, any agency thereof, or any of their contractors.

Printed in the United States of America. This report has been reproduced directly from the best available copy.

Available to DOE and DOE contractors from

Office of Scientific and Technical Information

P.O. Box 62

Oak Ridge, TN 37831

Prices available from (615) 576-8401, FTS 626-8401

Available to the public from

National Technical Information Service

U.S. Department of Commerce

5285 Port Royal Rd

Springfield, VA 22161

NTIS price codes

Printed copy: A03

Microfiche copy: A01

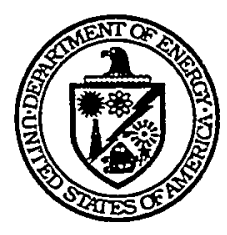




\section{DISCLAIMER}

Portions of this document may be illegible in electronic image products. Images are produced from the best available original document. 
SAND99-8519

Unlimited Release

Printed April 1999

\title{
Attributes of a Research Environment That Contribute to Excellent Research and Development
}

\author{
G. B. Jordan and J. S. Binkley ${ }^{1}$ \\ Computational Reactive Processes Department \\ Sandia National Laboratories \\ PO Box 969 \\ L. D. Streit \\ McNeil Technologies \\ Springfield, Virginia
}

\begin{abstract}
This paper presents initial work at two U. S. Department of Energy (DOE) national laboratories to identify attributes of DOE Laboratory research environments that are most important for fostering excellent research. Thirty-six attributes in four areas were identified by scientists and engineers at these institutions and are presented using the Competing Values Framework as a model for discussing organizational effectiveness. These attributes served as the basis for the development of a self-assessment survey and improvement process designed specifically for research environments and administered to date to four research groups involving more than one thousand scientists and engineers. This approach to assessment reflects the complexity of the research environment and provides information that allows the organization to define a few key actions for improvement.
\end{abstract}

'For more information contact Gretchen B. Jordan at gbiorda@sandia.gov or 202-314-3040. Dr. Jordan is a principal member of technical staff and Dr. J. Stephen Binkley is a senior scientist and manager at Sandia National Laboratories, Albuquerque, New Mexico and Livermore, California. L. Devon Streit is a senior analyst with McNeil Technologies, Springfield, Virginia. 


\section{Table of Contents}

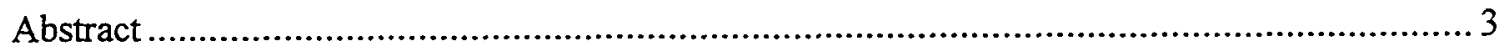

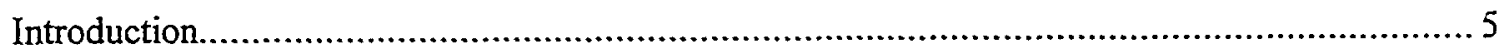

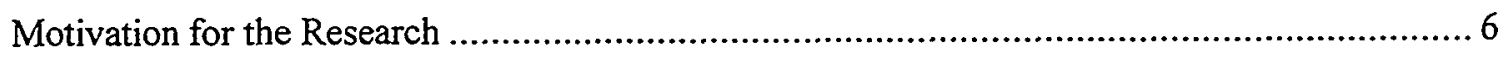

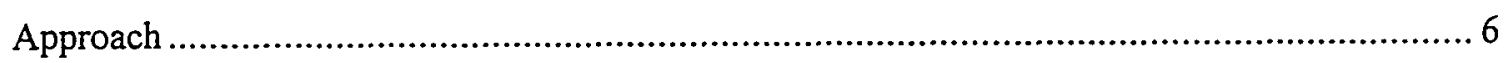

Thirty six Attributes That Foster Excellence in Research...................................................... 7

A Framework for R\&D Organizational Effectiveness..........................................................

The Competing Values Framework.............................................................................. 9

Organizing the Thirty six Attributes in Four Areas............................................................10

Assessing and Improving the Research Environment..........................................................11

Developing a Survey, Displaying the Results ...............................................................11

Designing a Process for Translating Findings into Action...................................................12

Comparison with Attributes Discussed in the Literature .........................................................12

Comparison of Attributes Across Laboratories and Type of Research........................................13

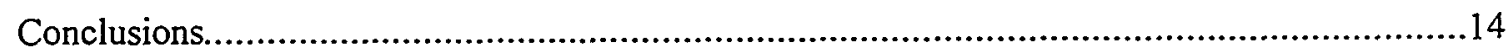

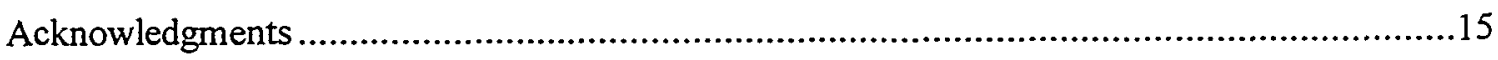

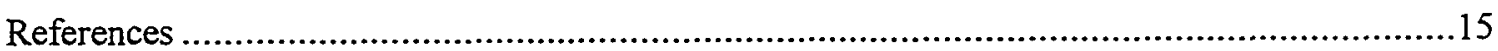




\section{Attributes of a Research Environment That Contribute to Excellent Research and Development}

\section{INTRODUCTION}

Increasingly, there is concern that the environment for conducting excellent research is deteriorating within the nation's large public research laboratories. This worry is being voiced both by the rank and file scientists within these institutions, as well as by leaders whose responsibility it is to steward the nation's research infrastructure (U.S House of Representatives, 1994). However, assessing the quality of research environments is made difficult by the lack of formal study that has been devoted to understanding environments in which excellent research and development (R\&D) occurs, including which attributes of the environment are most conducive to excellence.

This paper presents a study sponsored by the US Department of Energy's (DOE) Office of Basic Energy Sciences that was conducted at two of DOE's national laboratories. The study has two goals: understanding the key elements in research environments that contribute to the ability of staff to accomplish excellent research, and developing tools and processes for assessing and improving such environments. While one can cite individual examples to the contrary-e.g., Russian weapons scientists working in substandard facilities or computer software and hardware developers in their garages-a fundamental assumption of this study is that working in an excellent research environment increases the likelihood of producing excellent research. Furthermore, it is assumed that a good understanding of the attributes that lead to an excellent research environment, coupled with a straightforward tool and process for assessing those attributes, will enable managers to improve the research environment and therefore their organization's effectiveness. Finally, excellent research accomplishments and the emphasis on excellence, themselves contribute to a good research environment.

Through the use of focus groups, interviews and surveys, the research discussed in this paper has focused directly on scientists' and their managers' perceptions of what is important in a research environment. While it is possible that outside observers and management experts may have other ideas, gathering the opinions of those most involved seems to be necessary, if not sufficient, to an understanding of what is important in the research environment. There have been a few empirical studies that tie innovation and excellence in research to attributes in the research environment. To a large extent, the scientists' perceptions as reflected in this study are consistent with attributes identified in these empirical studies of excellent research organizations and outstanding researchers.

An understanding of the research environment is clarified by using a model that describes, albeit in simplified terms, the R\&D organization and the important attributes which contribute to its effectiveness. This model then highlights those attributes of the organization that are most important to assess, a major goal of this study. The Competing Values Framework proposed by Rohrbaugh (1983) and Rohrbaugh and Quinn $(1983,1988)$ is the model used for interpreting the thoughts and comments of the scientists and engineers in this study. It captures in a balanced way a broad array of competing perspectives on what contributes to effectiveness.

The research outlined in this paper has focused specifically on one type of research organization: that dealing primarily with physical sciences within Federal laboratories owned by the government and managed by private corporations. These laboratories are large, have specific research missions, and have annual budgets over $\$ 500$ million. Participants in the study perform basic and applied research as well as engineering and technology development. This study is limited to assessing the research environment, rather than measuring the outputs and outcomes of that environment, such as publications, citations, and new products. Future research will explore how research environments differ as a result of their cultures 
and their technical, economic, social and political/legal circumstances, and document the links between measures of the research environment and measures of outcomes.

\section{MOTIVATION FOR THE RESEARCH}

Research managers would like to know that their organization is doing all it can to provide an environment in which excellent research can be accomplished, and if not, to understand what can be done to improve the environment. Also, demonstrating that an organization is "effective" in the sense of optimizing the chances for producing new ideas and products-which are hard to predict in research-would indicate to investors that an organization is likely to provide a good return on their investment. But how can one know if a research environment is excellent?

Currently, employee attitude surveys and peer reviews are the primary means used by DOE laboratories to assess their workplaces. However, existing employee attitude surveys used by DOE laboratories fail to address many of the attributes identified as important by scientists in this study, such as the freedom to pursue new ideas, the level of commitment to critical thinking, the amount of cross fertilization of ideas, and the existence of a strong foundation of basic research. Peer review is generally well regarded by scientists but typically provides information at the project or program level. Because peer review results are seldom aggregated to organizational units above the project or programs they address, they are difficult to use to improve the research environment of the larger organization-frequently the locus where the authority to make fundamental change resides.

Thus, research managers have expressed a need for more data and better tools for assessing the research environments of their organizations. Are they succeeding at providing an environment conducive to performing excellent research and what can be improved? This study on assessing the research environment begins to fill this need.

\section{APPROACH}

Identification of important attributes in the research environments at the DOE national laboratories occurred within several research organizations over the course of almost two years. Nine focus groups were held, each consisting of approximately 10 scientists and R\&D managers. Groups were convened for either half-day or full-day sessions to identify and discuss research as an activity, and the attributes that contribute most to each scientist's ability to conduct excellent research. Participants were selected to meet a number of criteria. First, they were nominated by their management and peers for performing outstanding research and for being outspoken. In addition, the panels were constructed to reflect the make-up of research organizations at each laboratory along a number of dimensions: type of research (theoretical and experimental); scientific discipline (e.g., chemical and materials sciences); job responsibility ("bench" scientists, project managers, and senior managers); and experience (a mix of junior and senior researchers). The panels included both men and women (although not in equal proportions), and minorities. One panel was made up of administrative, computer and facilities support staff. The discussions of each panel were facilitated using a common set of questions and exercises, and a rapporteur captured the panelist's comments.

Each panel began with an exercise to define what "excellent research" meant for them. For example, one group"s definition of "Excellent Basic Research" is "research that produces new ideas and tools that advance the forefront of knowledge and has an enduring impact in areas of the DOE mission and national needs." Other groups determined that "Excellent Applied Research provides optimal solutions to a client's problems, offers a novel approach, and is accurate," and "Excellent Technology Development creates new systems, processes or gizmos that address national needs in a timely manner and are widely used." It was important for each group to have explored and developed a common view of "excellent 
research" in order for them to set their sights on an environment that would be conducive to such research. When each group reached agreement on a definition, the panelists were guided in a series of discussions to identify attributes of the work environment that contribute to their ability to perform excellent research. Panelists were asked to address attributes of their current research environment that were positive, as well as features that were detracting, missing, or insufficient. Finally, panelists were asked to describe attributes of the work environment that are necessary to hire and retain the best researchers.

One panel composed of fundamental research scientists participated in a formal exercise that required them to identify for each attribute: precursors, i.e. what must happen prior to an attribute being present; direct outcomes how the environment benefited as a result of the attribute; and the link to the desired outcome of excellent research. By clarifying these linkages, the panel members were able to provide insight into the aspects of each attribute. For example, the desire for "sufficient project funding" requires not only sufficient dollars to realize project goals, but that these dollars not be divided between so many researchers that none can devote sufficient time to the project. "Access to expertise in other disciplines," to give another example, is important because it encourages cross-fertilization of ideas within the laboratory, provides flexibility to staff new projects, and encourages awareness of other activities within the laboratory. These aspects of the attributes provided the information necessary to develop meaningful survey questions. In subsequent panels this exercise was accomplished by clarifying why the attribute was important as the group discussed it.

\section{Thirty six Attributes That Foster EXCELlenCe In RESEARCH}

To date, thirty-six attributes have been identified by scientists as most important to creating an environment that fosters excellent research. The thirty-six attributes reflect the complexity of science and technology research organizations and are arranged in four groups in Table 1 below.

Table 1. Thirty-six attributes that foster excellence in research.

\section{Human \& Physical Resource Development}

\begin{tabular}{|l|l|l|}
\hline 1. $\begin{array}{l}\text { Great } \\
\text { Facilities/Equipment }\end{array}$ & $\begin{array}{l}\text { Accessible equipment, state-of-the-art equipment in key areas, good } \\
\text { laboratory space and physical work environment. }\end{array}$ \\
\hline 2. & Quality of Colleagues & $\begin{array}{l}\text { Ability to attract and retain top quality colleagues, including post docs and } \\
\text { foreign nationals. }\end{array}$ \\
\hline $\begin{array}{l}\text { 3. } \\
\text { Strong Research } \\
\text { Competencies }\end{array}$ & $\begin{array}{l}\text { Existence of critical mass of staff and research projects in selected } \\
\text { research areas and disciplines. }\end{array}$ \\
\hline 4. & Sufficient Support Staff & $\begin{array}{l}\text { Sufficient technical/administrative support personnel so that everyone is } \\
\text { doing what they do best. }\end{array}$ \\
\hline $\begin{array}{l}\text { 5. } \\
\text { Sufficient, } \\
\text { Unfragmented Funding }\end{array}$ & $\begin{array}{l}\text { Sufficient funding to cover staff; also low fragmentation in funding so that } \\
\text { staff work on small number of projects; levels of funding consistent with } \\
\text { realistic project expectations. }\end{array}$ \\
\hline 6. $\begin{array}{l}\text { Opportunities for } \\
\text { Professional } \\
\text { Development }\end{array}$ & $\begin{array}{l}\text { Opportunities to advance both within the organizational hierarchy and } \\
\text { within one's professional field. }\end{array}$ \\
\hline 7. & Rewards for Merit & $\begin{array}{l}\text { Monetary and non-monetary rewards tied to merit; laboratory promotion } \\
\text { for national/international recognition and internal forms of recognition. }\end{array}$ \\
\hline 8. & $\begin{array}{l}\text { Competitive Salaries } \\
\text { and Benefits }\end{array}$ & $\begin{array}{l}\text { Salaries high enough to hire the best but fair within the laboratory } \\
\text { structure; benefits comparable to those of other laboratories. }\end{array}$ \\
\hline 9. & Respect for People & $\begin{array}{l}\text { Respect for diversity; trust and respect for people regardless of education } \\
\text { or job classification; management support for balancing work and home. }\end{array}$ \\
\hline
\end{tabular}


INNOVATION \& CROSS FiERTILIZATION OF IDEAS

10. Funding and Freedom to Pursue New Ideas

Resources available to pursue new ideas. Management that supports risktaking and can recognize good new ideas.

11. Sense of Challenge and Optimism

Enthusiasm for work. Optimism, that scientific and non-technical problems, can and will be solved. Stimulating and challenging work.

12. Autonomy in Scientific Management

The freedom and authority to direct the course of one's research; to pursue new ideas with customers.

13. Adequate Time to Do Research and Stay Current Adequate blocks of time, free from distraction, with which to think, be creative, perform and publish research.

14. Commitment to Critical Thinking

Individual and organizational commitment to internal constructive criticism; respect for the ideas of others; and commitment to the scientific method. Project decisions made on the basis of good science.

15. Internal Crossfertilization of Scientific/Technical Ideas Effective mechanisms and resources to facilitate interaction between and among disciplines. Support for multi-disciplinary approaches to problem solving.

16. External Collaborations and Interactions

Mechanisms, funding, and time to collaborate with individuals outside the laboratory; support for attendance at conferences and exchanges.

17. Effective External Reviews

Fair and effective use of peer and advisory committee reviews and other external sources of feedback. Efforts to prepare for reviews commensurate with benefits of reviews.

18. A Reputation for Excellence Laboratory and staff with a history, reputation, and documentation of producing excellent and relevant research. Senior management that champions the Laboratory's accomplishments.

MANAGEMENT \& INTERNAL PROCESSES

19. Fair, Well-planned $\quad$ Criteria for resource allocation are clear, known, and considered fair. Resource Allocation

20. Decisive, Informed $\quad$ Managers willing to make tough decisions. Managers knowledgeable Senior Management

21. Integrity of Line Management about staff research, and willing to stand up to DOE when it is wrong.

22. Value-added Line Managers

23. Internal Cooperation and Teamwork

Credibility and trustworthiness; making decisions consistent with stated corporate values. Decisions based on data rather than personalities.

Managers with people skills, technical knowledge to represent their staff and the ability to protect staff from internal politics.

24. Good Internal Communication

25. Efficient Internal Systems and Processes

26. Efficient Lab Services Laboratory emphasis for teamwork and internal collaboration rather than turf battles and internal competition for resources.

Consistent, efficient communication within the laboratory regarding lab resources, how to get them, and on current lab activities; the willingness of people to share information.

Less "overkill" in policies \& procedures; simplified accounting systems; fewer budget drills; simplified project approval \& reporting requirements.

Competent, efficient, user-friendly, lab-wide services such as library, routine analytical capabilities, graphics, computer support, facilities management/security and compliance monitoring.

27. Competitive Overhead $\quad$ A competitive cost structure that allows a ratio of "direct" costs, such as Rates salaries and materials to "indirect" costs, such as laboratory administration, that is comparable to those of other DOE labs.

SETTING \& ACHIEVING RELEVANT GOALS

28. Clear and Compelling Research Vision for understanding lab-level resource allocation, hiring, and other 


\begin{tabular}{|l|l|}
\hline & $\begin{array}{l}\text { decisions. General belief that the lab is headed in the right direction and } \\
\text { that one's research is consistent with that vision. }\end{array}$ \\
\hline $\begin{array}{l}\text { 29. Continuity in Funding, } \\
\text { Research Themes }\end{array}$ & $\begin{array}{l}\text { Consistent research directions and themes; projects funded on a multi- } \\
\text { year basis. Clear links between customer needs and organizational goals; } \\
\text { researchers that see their projects as part of larger lab research themes. }\end{array}$ \\
\hline $\begin{array}{l}\text { 30. Investment in Future } \\
\text { Capabilities }\end{array}$ & $\begin{array}{l}\text { Laboratory with long-term planning horizon; willingness to invest in new } \\
\text { projects and future areas of research (e.g., large-scale capital equipment, } \\
\text { new facilities, new capabilities). }\end{array}$ \\
\hline $\begin{array}{l}\text { 31. Good Relationship With } \\
\text { Sponsors }\end{array}$ & $\begin{array}{l}\text { Good and direct relationship with sponsors/customers. Sponsors that are } \\
\text { aware of lab's research capabilities, and provide regular feedback. }\end{array}$ \\
\hline $\begin{array}{l}\text { 32. Systematic Process for } \\
\text { Identifying Project } \\
\text { Opportunities }\end{array}$ & $\begin{array}{l}\text { Existence of mechanisms for systematic scanning of organizational } \\
\text { opportunities and threats. Sufficient interaction between scientists and } \\
\text { marketers, with accountability for actions and results. }\end{array}$ \\
\hline $\begin{array}{l}\text { 33. Strong Foundation of } \\
\text { Basic Research }\end{array}$ & $\begin{array}{l}\text { Senior laboratory and contractor management that are committed to basic } \\
\text { research as a key component of the laboratory's portfolio. }\end{array}$ \\
\hline $\begin{array}{l}\text { 34. Integrated and Relevant } \\
\text { R\&D Portfolio }\end{array}$ & $\begin{array}{l}\text { Lab portfolio of R\&D projects with breadth and depth, high potential to } \\
\text { have an impact on mission and national needs. Strong integration between } \\
\text { basic and applied research, and technology development. }\end{array}$ \\
\hline $\begin{array}{l}\text { 35. Good Project Planning } \\
\text { and Execution }\end{array}$ & $\begin{array}{l}\text { Accountability for setting and meeting goals. Multi-year \& project } \\
\text { transition \& termination projects. Ability to get the product out the door. }\end{array}$ \\
\hline $\begin{array}{l}\text { 36. Appropriateness of } \\
\text { Laboratory's Measures } \\
\text { of Success }\end{array}$ & $\begin{array}{l}\text { Formal laboratory measures of success and rewards that are consistent } \\
\text { with doing excellent research. }\end{array}$ \\
\hline
\end{tabular}

A FRAMEWORK FOR R\&D ORGANIZATIONAL EFFECTIVENESS

\section{The Competing Values Framework}

Historically, the organizational effectiveness literature has articulated numerous perspectives on what makes an organization effective, that is, able to produce the desired outcomes. In an attempt to understand the relation of these perspectives to each other, Robert Quinn and John Rohrbaugh (1983) used multivariate analysis techniques to investigate the criteria used by organizational theorists and researchers to assess and conceptualize organizational effectiveness. Their work $(1983,1988)$ suggests that three "value dimensions" underlie conceptualizations of organizational effectiveness and can be used to organize the traditional and often conflicting "models" of effectiveness. The three value dimensions identified by Quinn and Rohrbaugh are organizational structure, organizational focus and the meansends continuum.

The dimension of organizational structure distinguishes between those activities and attributes that emphasize the organization's flexibility, adaptability, and breadth, versus those that stress control and stability. The dimension of organizational focus contrasts an emphasis on "internal issues" such as the well being and development of the people within the organization versus "external issues," such as the development and well being of the organization itself or its relations with entities outside itself. The means-ends continuum reflects the contrast between the concern for the objectives of the organization, such as productivity or human resource development, and the means by which it achieves these objectives, for example goal setting or enhancing morale. 
As illustrated in Figure 1, Quinn and Rohrbaugh have used these value dimensions as axes with which to organize four of the most common theoretical models of organizational

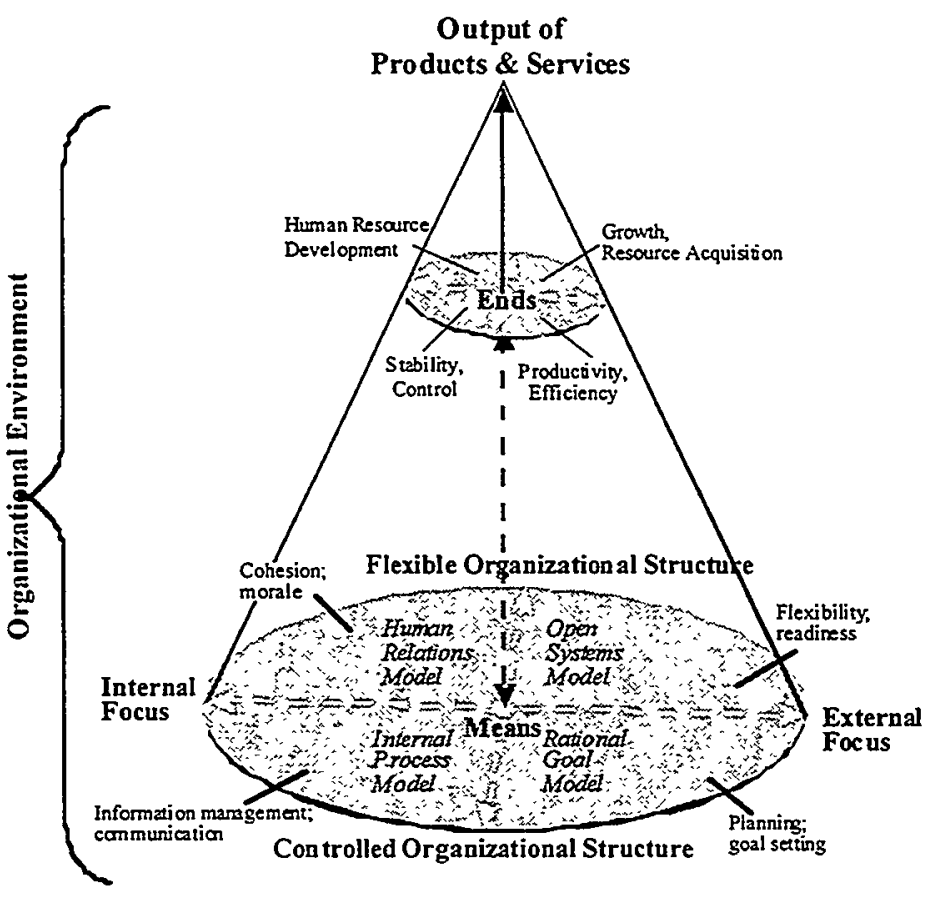

Figure 1. The Competing Values Framework incorporates four common models of organizational effectiveness. effectiveness: the human relations model, the open systems model, the rational goal model, and the internal processes model. Each of the four models stresses the importance of different attributes in creating an effective organization. Quinn and Rohrbaugh's Competing Values Framework, as this construct is called, explicitly recognizes that different individuals will emphasize different sets of means and ends within an organization depending on their own personal values and on the type of organization in question. Each of these ways of viewing what is "effective" or to be valued in an organization has deep roots in the organizational effectiveness literature and organizational theory, as well as in individual values and biases. Furthermore, each perspective suggests different solutions to the question, "what could be done to make this research environment more effective?" Use of the Competing Values Framework captures a wide range of views on what is important in a research environment and thus reflects the

complexity of these organizations. Furthermore, it addresses the tensions between focusing internally and looking outward, between striving for flexibility or innovation and trying to provide stability, that are reoccurring themes in scientists' and managers' discussions of their research environments.

\section{Organizing the Thirty six Attributes in Four Areas}

In Table 1 and in the discussion below, the attributes of the research environment are organized according to their fit within the quadrants of the Competing Values Framework. Altschuld and Zheng (1995) first proposed using the Competing Values Framework for assessing R\&D organizations, but they did not take the next step of describing the accompanying attributes of organizational structure and focus. Refinements to this organization of attributes as more data are gathered and analyzed is expected, however this structure appears to provide a good starting point for discussing scientists' perceptions of $R \& D$ organizational effectiveness.

The human relations model emphasizes a view that values internal focus and flexibility within the organization. A good organization from this perspective is one that emphasizes good morale and cohesion, and results in human resource development. Several attributes identified by scientists in this study relate to resource development-human, physical and intellectual. These include excellent facilities and equipment, the highest quality colleagues, strong research competencies, sufficient and unfragmented funding, opportunities for professional development, rewards for merit, competitive salaries and benefits, and respect for people.

The open system model stresses flexibility and an external focus as being the keys to organizational effectiveness. "Good" from this perspective is often measured by flexibility and readiness or outcomes of those, such as growth and resource acquisition. Attributes proposed by scientists in this area are categorized in this study as innovation and cross-fertilization of ideas. Attributes include funding and 
freedom to pursue new ideas, sense of challenge and optimism, autonomy in scientific management, adequate time to do research and stay current in one's field, commitment to critical thinking, internal cross-fertilization, external collaborations and interactions, effective external reviews, and a reputation for excellence.

The rational goal model differs from the two models discussed above in its emphasis on the value of control and stability over flexibility and readiness. An effective organization from this perspective is discussed in terms of planning and goal-setting which results in productivity and efficiency. In the area of setting and achieving relevant goals scientists identified a clear and compelling research vision, continuity in funding and research themes, investment in future capabilities, good relationship with sponsors, a systematic process for identifying project opportunities, strong foundation of basic research, an integrated and relevant $R \& D$ portfolio, good project planning and execution, and the appropriateness of the laboratory's measures of success.

The internal process model also values control and stability, but unlike the rational goal model, emphasizes an internal focus. It values the role of information management, communication systems, and the internal structures and routines that provide employees with a sense of organizational continuity and security. Attributes identified in this study in the area of management and internal processes include fair, well-planned resource allocation, decisive and informed senior management, the integrity of line management, the value added by line managers, internal cooperation and teamwork, internal communication, efficient internal systems and lab services, and competitive overhead rates.

\section{ASSESSING AND IMPROVING THE RESEARCH ENVIRONMENT}

\section{Developing a Survey, Displaying the Results}

The thirty-six attributes provide a basis for a survey designed to measure a profile of a research environment, rather than provide a single measure of its quality. The survey is divided into five parts: detailed questions about the thirty six individual attributes, questions about the importance of each attribute and which five should be the focus of improvement, questions about changes in areas where improvement actions were identified last year, questions on overall impressions some of which allow for longer answers, and requests for demographic information.

From the survey response, illustrations similar to the one shown here in Figure 2 can be built that depict the current and desired states of an organization. Each radiating spoke represents a rating of an attribute, with " 5 " being "outstanding." The higher the average numeric response the more positively the respondents viewed that attribute of their environment. The figure shows how perceptions may differ in three organizations. In each, the darker shaded areas reflect attributes of the research environment as staff perceive them today, while the lighter shaded areas show the attributes the organizations most wish to improve.

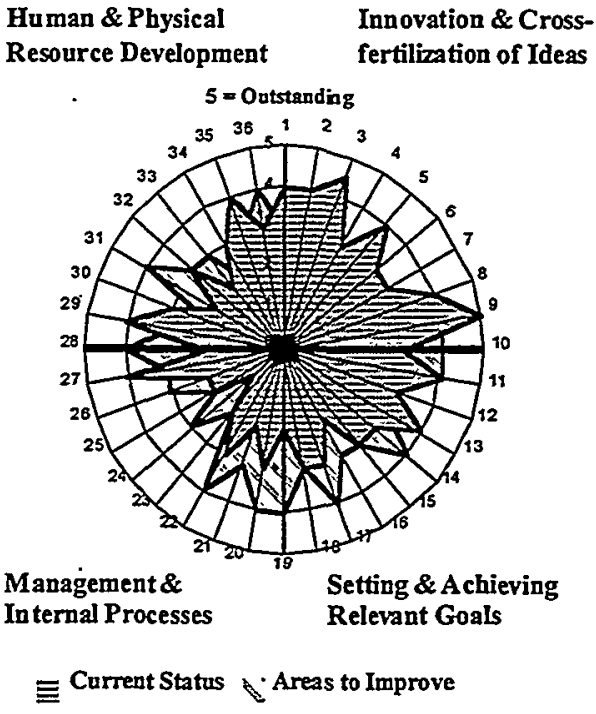

Figure 2. A profile of the research environment displays staff perceptions on thirty-six attributes. 


\section{Designing a Process for Translating Findings into Action}

From the outset of the assessment efforts, the study chose to focus the survey at the level of the organization where change can most readily be made. In one laboratory this was a "Center" level (about 100 staff each) and at another it was a "Division" level of approximately 700 staff divided into Technical Resource Areas of 30-60 staff each. In all cases, those participating in the assessment process expressed concern that failure to take action subsequent to surveying would have a substantial negative effect on their research environment. This study has worked closely with the organizations' management to develop an improvement process that would allow the organization to interpret the results of the survey and be guided in the development of actions. These improvement processes included common activities:

- full participation by the organization leader and all staff;

- administration of the survey in small groups with discussion afterward;

- guaranteed anonymity for survey respondents;

- interpretation of aggregated survey results and corroborating data by the organizations themselves; and

- facilitated session(s) subsequent to the presentation of survey results to select a few key actions for the organization to implement.

To date the survey has been administered to three research centers within one laboratory and to a division of approximately 700 scientists and support staff in another laboratory. In each case, the results have provided the organization's managers and staff with concrete information from which to craft actions to improve their research environment. Specifically, information is provided to the surveyed organization on what their organization is doing well and not so well, what they believe is most important to their organization, and what few items they wish the organization would focus on improving in the coming year. As illustrated in Figure 3, information in these three dimensions allows management and staff to select activities that are most likely to have a positive impact on the environment. Examples of actions chosen by the organizations surveyed to date include increasing the ratio of post doctoral scientists and technicians to research staff, reducing the average number of accounting cases each researcher charges his/her time to, increasing the time available to researchers to perform research, and developing and communicating a more compelling research vision within the organization.

\section{COMPARISON WITH ATTRIBUTES DISCUSSED IN THE LITERATURE}

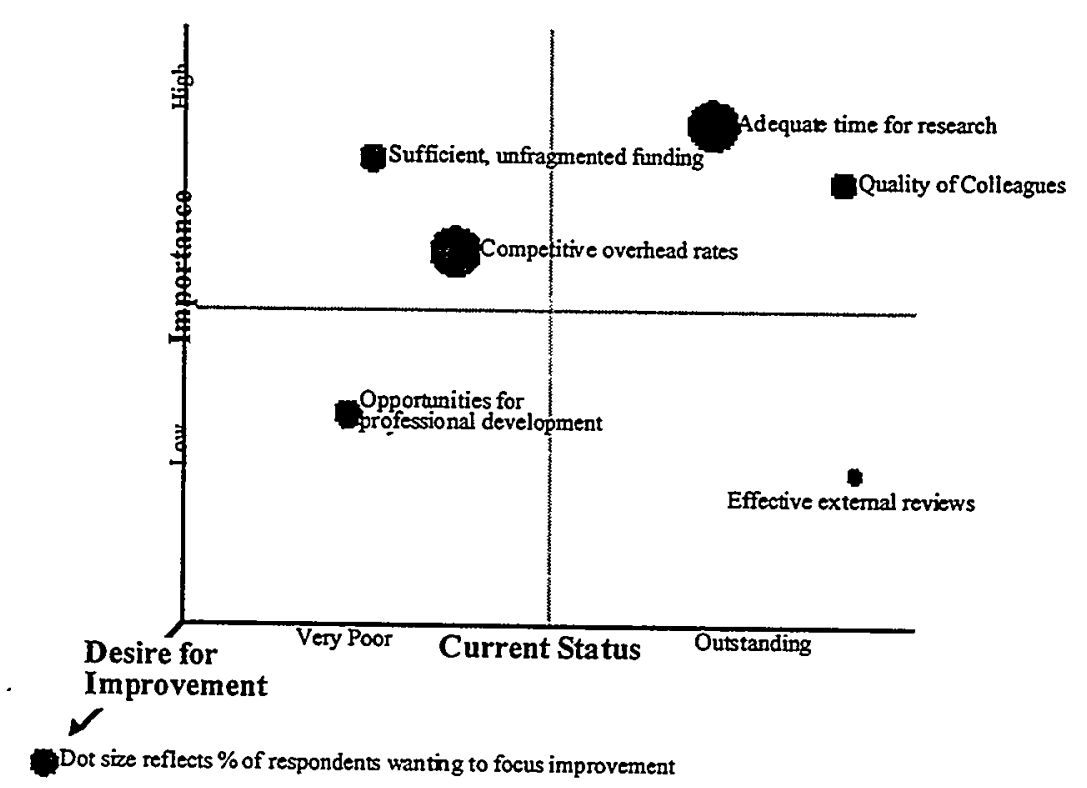

The attributes defined in this study are similar to those mentioned in the more comprehensive discussions of the organization of research and the management of innovation. For example, the framework used in the Minnesota Innovation Research Program (Van de Ven and Chu, 1989) suggests that perceived innovation effectiveness is a function of characteristics of the innovation idea, leadership, procedures and relationships, and organizational context. The Multiple Perspectives Model put forth in F. E. Udwadia's paper (1990) ties creative behavior and performance to three perspectives: individual characteristics 
associated with creativity, needed technical resources (material as well as human) for creativity, and organizational practices and managerial actions that aid or stifle creativity. A National Research Council study (1996) identified five pillars of a world class Army research, development and engineering organization: customer focus, resources and capabilities, strategic vision, value creation, and quality focus. Bland and Ruffin's (1992) synthesis of thirty years of studies concludes that thirteen characteristics were consistently related to research productivity. Decentralized organization, appropriate rewards, and accessible resources are among those characteristics that are similar to those defined in this study.

The thirty-six attributes also include organizational factors related to innovation that are similar to attributes mentioned by other authors whose focus is innovation. For example, John Hurley (1997), in a study based on interviews with Nobel Prize winners, describes individual and organizational characteristics and resources that lead to scientific discovery. Among these many are consistent with those identified in this study such as the need to be free to think and experiment, respect for the scientists' freedom and autonomy, and staffing that allows cross-disciplinary discussion. Frank Hull (1988) concludes from a study of 110 U.S. factories that, for small scale, technically complex workloads, invention rates are more proportional to $R \& D$ input if the organization design is organic-professional rather than mechanistic-bureaucratic. Organic organizations keep mechanistic barriers low, are decentralized, and use integrative devices such as cross-functional teams.

The attributes revealed in this study are also among measures identified in studies that look for appropriate metrics for R\&D performance. In addition to measures of outputs and outcomes, Hauser and Zettelmeyer $(1996,1997)$ of the MIT/Sloan International Center for Research on the Management of Technology suggest that appropriate measures for the performance of basic and more applied R\&D include quality of the personnel, managerial involvement, and match to organization's strategic goals. Based on four years of data collection with the Industrial Research Institute, Ellis (1997) suggests that the most important evaluation measurements of internal processes to effectively control innovation management are to measure the rewards in use, the degree of flatness of the internal organization, and top management commitment.

Finally, the attributes identified in this study are included among the attributes that several studies conclude are linked to excellence and quality outcomes. Some examples have already been mentioned above. Another example is the seven best R\&D practices identified by Ransley and Rogers (1994) as the best practices identified by at least three of four respected consulting companies from their studies and experience. The seven practices encompass technology strategies, program selection and management, core strengths, effectiveness, external awareness, technology transfer, and a "personnel" category that includes people-related issues. Lastly, Menke (1997) identified through quantitative analysis of the behavior of 79 leading R\&D organizations, ten practices as most essential for R\&D strategic excellence. Six of Menke's ten are similar to attributes identified in this study.

\section{Comparison of Attributes ACross laboratories and TyPe of ResearCH}

Because the two DOE laboratories are different-in history, size, who sponsors their research, and other ways, one would expect the attributes they find important would differ. Nevertheless, work with these laboratories thus far indicates a substantial similarity in what the scientists within these organizations believe is important. Where differences occurred they were primarily differences in emphasis. For example, having a compelling laboratory research vision was a high priority for scientists at one laboratory but not at the other. Similarly, while management issues were important to both laboratories, one focused on its management's visibility, credibility and people skills, while the other stressed attributes of the management structure and scientists' continued ability to direct the course of their research. As the efforts of this study are extended to additional government laboratories as well as industry and university-managed laboratories, it is expected that substantial similarities and significant differences will be found in what each laboratory considers important to the research environment. The 
ability to explain these differences in light of the different cultures and circumstances present at the laboratories will be a future topic of this research.

In addition to differences between laboratories, initial observations from this study suggest that there is a consistent difference of opinion between basic researchers, applied researchers, and technology developers about what is important in the environment to achieve excellence. For example, basic researchers consistently rank the need for time to do work and the freedom to pursue innovative ideas as among the top attributes important to the research environment. Applied researchers emphasize issues of fairness in resource allocation (e.g., allocations of internal R\&D funds) and the need for improved collaboration among scientists from different parts of the laboratory. Technology developers stress the need for more systematic and effective identification of project opportunities. One significance of this observation is that different sub-groups within the R\&D community believe they need different attributes in the environment to maximize their ability to perform excellently. Thus the fact that actions taken to improve the environment for one sub-group may not be those desired by another must be taken into account when any actions are being considered.

\section{CONCLUSIONS}

The thirty-six attributes identified in this study provide an understanding of the key contributors to an excellent research environment and lay the foundation for a consistent framework from which to assess such organizations. Many of the thirty-six attributes identified by scientists have been identified in other studies of research organizations and scientific achievement. Many are, in fact, captured by currentlyused employee satisfaction surveys. However, others reflecting attributes of the R\&D environment more closely related to innovation and the cross-fertilization of ideas are new to these types of surveys, and have the potential to offer insights specific to excellence in research institutions.

Grounding the development of the survey in the Competing Values Framework of organizational effectiveness theory has provided a useful means to make explicit what scientists and engineers voiced in numerous focus groups and interviews. Research environments and the decisions research and laboratory managers make are defined by many tensions and trade-offs: between organizational stability and individual flexibility; between attention to the internal workings of the organization and collaboration with the outside world; between attention to organizational objectives and attention to the processes by which these objectives are achieved.

The ability to reflect the complexity of the research organization while presenting information in a way that easily allows groups of scientists and managers to identify actions is critically important. The cynicism with which staff in most organizations meets satisfaction surveys of any sort is palpable, thus the ability to condense large quantities of staff perceptions and concerns into information that the organization can use is absolutely crucial. Equally important is the existence of a person at the top of the organizational structure willing to initiate change and ensure creation of an improvement process that involves all stakeholders. The assessment tool developed in this study, with a thoughtful and dynamic improvement process, has been used successfully to implement action plans to improve the research environment. 


\section{ACKNOWLEDGMENTS}

The authors acknowledge the vision, support and funding of Patricia Dehmer and Iran Thomas of the U.S. Department of Energy Office of Basic Energy Sciences. Research has been performed under contract DE-AC04-94AL85000 with Sandia National Laboratories. The authors thank the study's champions within the laboratories who also made the research possible: Tom Hunter, Robert Eagan, Tom Picraux, Bill McLean, Mike Dyer, Gerry Stokes and Ray Stults. The opinions expressed are those of the authors, not the U.S. Department of Energy.

\section{REFERENCES}

J. W. Altschuld and H. Y. Zheng, "Assessing the Effectiveness of Research Organizations: An Examination of Multiple Approaches," Evaluation Review, vol. 19, 1995, pp. 197-216.

C. J. Bland and M. T. Ruffin, "Characteristics of a Productive Research Environment," Academic Medicine, vol. 67, 1992, 385-397.

L. Ellis, Evaluation of R\&D Processes: Effectiveness through Measurements (Boston, MA: Artech House, 1997).

J.R. Hauser, "Research, Development, and Engineering Metrics," Working Paper \#145-96, International Center for Research on the Management of Technology, 1996 (Revised January 1997.)

J. R. Hauser and F. Zettelmeyer, "Metrics to Evaluate R,D\&E," Research · Technology Management, Vol. 40, No.4, July-Aug 1997, pp. 32-38.

F. M. Hull, "Inventions from R\&D: Organizational Designs for Efficient Research Performance," Sociology, Vol. 2, 1988, pp. 393-415.

J. Hurley, Organisation and Scientific Discovery (New York, NY: John Wiley \& Sons, 1997).

M. M. Menke, "Essentials of R\&D Strategic Excellence," Research - Technologv Management, Vol. 40, No. 5, Sept-Oct 1997, pp. 42-47.

National Research Council, "World-Class Research and Development: Characteristics of an Army Research, Development, and Engineering Organization," National Academy Press, 1996.

R. E. Quinn, "The Competing Values Model: Redefining Organizational Effectiveness and Change," Beyond Rational Management: Mastering the Paradoxes and Competing Demands of High Performance (San Francisco, CA: Jossey-Bass, 1988).

R.E. Quinn and J. Rohrbaugh, "A Spatial Model of Effectiveness Criteria: Towards a Competing Values Approach to Organizational Analysis", Management Science, 29, No. 3, March 1983: 363-73.

D. Ransley and J. Rogers, "A Consensus on Best R\&D Practices," Research - Technology Management, Vol. 37, No. 2, Mar-Apr 1994, pp. 19-26.

J. Rohrbaugh, "The Competing Values Approach: Innovation and Effectiveness in the Job Service," Organizational Theory and Public Policy, Eds. R.H. Hall and R.E. Quinn, (Beverly Hills, CA: Sage, 1983). 
F. E. Udwadia, "Creativity and Innovation in Organizations: Two Models and Managerial Implications," Technological Forecasting and Social Change, vol. 38, 1990, pp. 65-80.

US House of Representatives, $103^{\text {rd }}$ Congress, "Science in the National Interest", Hearing before the Subcommittee on Science of the Committee on Science, Space, and Technology, August 4, 1994, 4.Sci 2:103/149.

A.H. Van de Ven and Y. Chu, "A Psychometric Assessment of the Minnesota Innovation Survey," Research on the Management of Innovations: The Minnesota Studies, Van deVen, Angle and Poole (Eds). New York: Harper and Row, 1989, pp. 55-98. 


\section{DISTRIBUTION:}

2 Pat Dehmer

US DOE, SC-10

19901 Germantown Rd.

Germantown, MD 20874-1290

2 Iran Thomas

US DOE, SC-10

19901 Germantown Rd.

Germantown, MD 20874-1290

1 Bill Kirchhoff

UD DOE, SC-10

19901 Germantown Rd.

Germantown, MD 20874-1290

1 Don Freeburn

US DOE, SC-10

19901 Germantown Rd.

Germantown, MD 20874-1290

25 Gretchen Jordan

Sandia National Laboratories, MS 1393

950 L'Enfant Plaza SW, Suite 110

Washington, DC 20024

$\begin{array}{lll}1 & \text { MS 0127 } & \text { Sheryl Hingorani, 4141 } \\ 1 & \text { MS 0177 } & \text { Don Schueler, 4151 } \\ 1 & \text { MS 0511 } & \text { John Cummings, 1001 } \\ 1 & \text { MS 0513 } & \text { Robert Eagan, 1000 } \\ 1 & \text { MS 0635 } & \text { Glenn Kuswa, 12365 } \\ 1 & \text { MS 0724 } & \text { Joan Woodard, 6000 } \\ 1 & \text { MS 1349 } & \text { Allan Hurd, 1841 } \\ 1 & \text { MS 1421 } & \text { John Sullivan, 1153 } \\ 1 & \text { MS 1427 } & \text { Tom Picraux, 1100 } \\ 1 & \text { MS 9001 } & \text { M. E. John, 8000 } \\ 1 & \text { MS 9002 } & \text { Pat Smith, 8300 } \\ 1 & \text { MS 9041 } & \text { Steve Binkley, 8345 } \\ 1 & \text { MS 9051 } & \text { Jackie Chen, 8351 } \\ 1 & \text { MS 9054 } & \text { Bill McLean, 8300 } \\ 1 & \text { MS 9055 } & \text { Dave Chandler, 8353 } \\ 1 & \text { MS 9056 } & \text { Larry Rahn, 8351 } \\ 1 & \text { MS 9161 } & \text { Bob Hwang, 8716 } \\ 1 & \text { MS 9405 } & \text { Mike Dyer, 8700 } \\ & & \\ 3 & \text { MS 9018 } & \text { Central Technical Files, 8940-2 } \\ 1 & \text { MS 0899 } & \text { Technical Library, 4916 } \\ 1 & \text { MS 9021 } & \text { Technical Communications Department, 8815/ } \\ & & \text { Technical Library, MS 0899, 4916 } \\ 1 & \text { MS 9021 } & \text { Technical Communications Department, 8815 For DOE/OSTI }\end{array}$


This page intentionally left blank 